Article

\title{
Preparation of solid acid catalyst from rice husk char and its catalytic performance in esterification
}

\author{
Ming Li, Dengyu Chen, Xifeng Zhu* \\ Key Laboratory for Biomass Clean Energy of Anhui Province, University of Science and Technology of China, Hefei 230026, Anhui, China
}

\section{A R T I C L E I N F O}

Article history:

Received 2 April 2013

Accepted 31 May 2013

Published 20 September 2013

Keywords:

Rice husk char

Solid acid catalyst

Biodiesel

Esterification

\begin{abstract}
A B S T R A C T
A sulfonated carbon-based solid acid catalyst was prepared by sulfonating rice husk char with concentrated sulfuric acid. The as-prepared catalyst was characterized using X-ray diffraction, X-ray photoelectron spectroscopy, ultimate analysis, specific surface area analysis, and thermogravimetry-mass spectrometry. The effects of the sulfonation temperature and time on the catalytic performance were investigated using the esterification of oleic acid and methanol as the probe reaction. The effects of the reaction conditions on the esterification catalyzed by sulfonated rice husk char were also studied. The stability of the catalyst was examined. The results showed that $90{ }^{\circ} \mathrm{C}$ and $0.25 \mathrm{~h}$ were suitable sulfonation temperature and time, respectively. The catalyst prepared under these conditions had an amorphous carbon structure with a sulfonic group concentration of 0.7 $\mathrm{mmol} / \mathrm{g}$. It exhibited high catalytic performance. The conversion of oleic acid was $98.7 \%$ under the optimal reaction conditions with a catalyst amount of $5 \%$, a methanol to oleic acid molar ratio of $4: 1$, and a reaction temperature and time of $110^{\circ} \mathrm{C}$ and $2 \mathrm{~h}$, respectively. The esterification conversion still reached $96.0 \%$ after seven cycles of successive reuse, which indicated that the catalyst stability was excellent.
\end{abstract}

(C) 2013, Dalian Institute of Chemical Physics, Chinese Academy of Sciences. Published by Elsevier B.V. All rights reserved.

\section{Introduction}

Biodiesel, a type of green fuel, has the advantages of a low sulfur content, being non-toxic and biodegradable, lack of aromatics, excellent lubricity, a high flash point, and a high cetane value [1,2]. The most widely used industrial method for the commercial production of biodiesel is the transesterification process [2], in which a triglyceride, the main ingredient of vegetable oils or fats, undergoes an alcoholysis reaction with a lower alcohol and produces the corresponding fatty acid esters, i.e., biodiesel. The major obstacle to the development of the biodiesel industry is the high cost of feedstock [3-6], which accounts for $70 \%-95 \%$ of the total cost according to some sta- tistics [7-9]. The use of low-priced feedstocks such as waste cooking oils, inedible oils, animal fats, and soapstock is the key to achieving industrialization and commercialization of biodiesel [10]. However, these feedstocks usually contain considerable amounts of free fatty acids, which adversely affect the transesterification process (for which an acid value of $1.5 \mathrm{mg}$ $\mathrm{KOH} / \mathrm{g}$ of feedstock is favorable) [6,8], and must be converted to their corresponding esters through pre-esterification $[1,5]$. This process is generally catalyzed using concentrated sulfuric acid $[11,12]$, but sulfuric acid is difficult to recycle, causes serious corrosion problems, and leads to discharge of large amounts of effluents.

Recently, a carbon-based solid acid catalyst prepared from

\footnotetext{
*Corresponding author. Tel: +86-551-63600040; Fax: +86-551-63606689; E-mail: xfzhu@ustc.edu.cn This work was supported by the National High Technology Research and Development Program (863 Program, 2012AA051803), the National Natural Science Foundation of China (50930006), and the Key Research Program of the Chinese Academy of Sciences (KGZD-EW-304-3). 
saccharides and biomasses by incomplete carbonization followed by sulfonation has attracted much attention from numerous researchers because of its low preparation costs and high catalytic activity [5,13-21]. Toda's group [17,18] studied the esterifications of acetic acid and oleic acid catalyzed by solid acid catalysts prepared by sulfonation of incompletely carbonized glucose and sucrose. The results showed that the catalytic activity in the esterifications of acetic acid and oleic acid with ethanol was $1 / 7$ and $1 / 2$, respectively, compared with that of concentrated sulfuric acid, but it was superior to that of niobic acid. Chen et al. [19] prepared a solid acid catalyst from a glucose-starch mixture and used it to catalyze the esterification of oleic acid and methanol. The results showed that the conversion of oleic acid was $96 \%$ using a methanol to oleic acid molar ratio of $10: 1$ and a reaction temperature of $80{ }^{\circ} \mathrm{C}$ for $6 \mathrm{~h}$. Lou et al. [20] prepared four kinds of solid acid catalysts from glucose, sucrose, starch and cellulose and explored their esterification and transesterification activity. The starch-derived catalyst showed the highest activity, rivaling that of concentrated sulfuric acid. Kastner et al. [21] synthesized solid acid catalysts by sulfonating biochar from peanut hull and wood chip pyrolysis processes. The catalysts displayed good catalytic performance for esterifications of palmitic acid and stearic acid, and the conversion of palmitic acid approached nearly $100 \%$. The fast pyrolysis of biomass produces about $15 \%-25 \%$ of solid char [22]. Its effective and high-value use will significantly improve the bio-oil economy.

In this work, a solid acid catalyst was prepared from char obtained by rice husk pyrolysis, and the catalytic activity in the esterification of oleic acid and methanol as a probe reaction was evaluated under different catalyst dosages (based on the oleic acid mass), methanol to oleic acid molar ratios, and reaction temperatures and times. The stability of the as-prepared catalyst was also investigated to further evaluate the catalyst.

\section{Experimental}

\subsection{Catalyst preparation}

The char obtained by rice husk pyrolysis was ground to powder (particle size $\leq 0.28 \mathrm{~nm}$ ) and then sulfonated using concentrated sulfuric acid (95\%-98\%) at a certain temperature for a given time (the char mass to concentrated sulfuric acid volume ratio was $1 \mathrm{~g}$ to $10 \mathrm{ml}$ ). After cooling to ambient temperature, the mixture was added to distilled water, stirred, and filtered. The precipitate was then washed repeatedly with hot distilled water until the filtrate was free from sulfate ions. Following filtration, the sample was dried at $80{ }^{\circ} \mathrm{C}$ for $24 \mathrm{~h}$ in a drying oven, bagged, and placed in a desiccator.

\subsection{Catalyst characterization}

The ratios of $\mathrm{C}, \mathrm{H}, \mathrm{N}$, and $\mathrm{S}$ were determined using an elemental analyzer (Elementar Vario MICRO, Germany). The ratio of $\mathrm{O}$ was determined using an elemental analyzer (Elementar Vario EL cube, Germany). X-ray diffraction (XRD) analysis was conducted with a powder X-ray diffractometer (MacScience
MXPAHF, Japan), using $\mathrm{Cu} K_{\alpha}$ radiation $(\lambda=15.4056 \mathrm{~nm})$ at 30.0 $\mathrm{kV}$ and $150.0 \mathrm{~mA}$, in the scanning angle range $(2 \theta) 10^{\circ}-70^{\circ}$ at a scanning speed of $8^{\circ} / \mathrm{min}$. The sulfur-containing species were determined by X-ray photoelectron spectroscopy (XPS; Thermo-VG Scientific ESCALAB 250, USA), using an Al $K_{\alpha}$ X-ray source, the constant analyzer energy mode, and an energy step size of $1.00 \mathrm{eV}$. The specific surface area and the pore size of the catalyst were determined using an automatic surface area and pore analyzer (Quantachrome Quandasorb SI, USA). The specific surface area was determined using the Brunauer-EmmettTeller (BET) equation at a relative pressure of $0.05-0.2$. The total pore volume was estimated to be the liquid volume of $\mathrm{N}_{2}$ adsorbed at a relative pressure of 0.99 , and the average pore size was measured using the Barrett-Joyner-Halenda (BJH) method based on the desorption data. Prior to analysis, the sample was degassed under $\mathrm{N}_{2}$ at $100{ }^{\circ} \mathrm{C}$ for $3 \mathrm{~h}$. Thermogravimetric analysis-mass spectrometry (TG-MS) was performed using a thermogravimetric analyzer (Perkin Elmer Pyris 1, USA) and a mass spectrometer (Perkin Elmer Clarus SQ 8, USA). The mass to charge ratio was detected using a multi-channel ion detection system; the furnace temperature for TGA was increased from ambient temperature to $800{ }^{\circ} \mathrm{C}$ under a helium flow of $50 \mathrm{ml} / \mathrm{min}$ at a heating rate of $10{ }^{\circ} \mathrm{C} / \mathrm{min}$. The number of strong acid sites was determined by titration [23,24]. In a typical experiment, $0.5 \mathrm{~g}$ of catalyst was dispersed in $50 \mathrm{ml}$ of $\mathrm{NaCl}$ solution ( $1 \mathrm{~mol} / \mathrm{L}$ ) in a $100 \mathrm{ml}$ conical flask, oscillated on an ultrasonic vibration meter for $30 \mathrm{~min}$ and filtered. The filtrate was titrated with $\mathrm{NaOH}$ solution $(0.1 \mathrm{~mol} / \mathrm{L})$.

\subsection{Catalyst performance}

The esterification of oleic acid with methanol was carried out in a continuous esterification apparatus with a rectifying column [16]. This apparatus consisted of a reactor and a reboiler, which removed water but not methanol from the reactor at high reaction temperatures.

The equipment was preheated to the given temperature (the temperature of the reboiler was $70{ }^{\circ} \mathrm{C}$ ), and then the catalyst, oleic acid, and methanol were added sequentially. The mixture was stirred using a magnetic stirrer at a speed of 800 $\mathrm{r} / \mathrm{min}$. Samples were removed at specified time for analysis.

The conversion of oleic acid (defined as $X$ ), determined by the acid value of the oil layer, was used to measure the catalytic activity [6,25]: $X=\left(1-\mathrm{AV}_{t} / \mathrm{AV}_{0}\right) \times 100 \%$, where $\mathrm{AV}_{t}$ is the final acid value and $A V_{0}$ is the acid value of oleic acid. The acid value was determined according to GB/T 5530-2005.

All the cycles for investigating the stability of the catalyst were carried out using a catalyst amount of $5 \%$, a methanol to oleic acid molar ratio of $4: 1$, and an esterification temperature of $110{ }^{\circ} \mathrm{C}$ for a given time. After each run, the catalyst was recovered by filtration [4].

\section{Results and discussion}

\subsection{Characteristics of solid acid catalyst}

The XRD pattern of the solid acid catalyst obtained from rice 


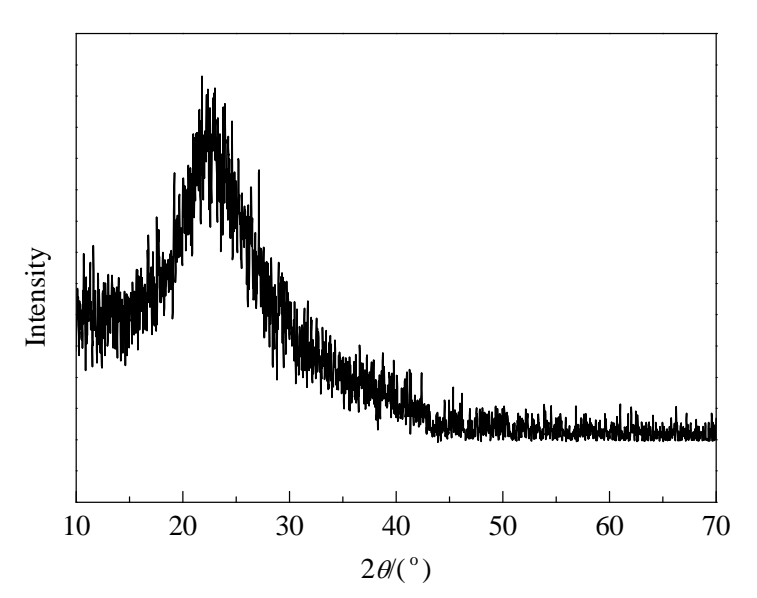

Fig. 1. XRD pattern of solid acid catalyst obtained from rice husk char.

husk char is shown in Fig. 1. It had a broad peak centered at $2 \theta$ $=22.3^{\circ}$, attributable to the characteristic peak of $\mathrm{C}(002)$, but the $\mathrm{C}(100)$ and $\mathrm{C}(004)$ peaks did not appear, which showed that the catalyst was amorphous carbon with a low degree of graphitization [26]. Because catalysts prepared from graphite, carbon black, and glassy carbon displayed no catalytic activity in the esterification reaction [13], it was inferred that the amorphous structure played an important role in the catalytic process $[5,8]$.

Figure 2 shows the narrow survey scan for the $S 2 p$ region in XPS of the catalyst. A single S $2 p$ peak was observed at 168.4 $\mathrm{eV}$, which indicated that all the $\mathrm{S}$ atoms in the catalyst were contained in $-\mathrm{SO}_{3} \mathrm{H}$ groups [17-19]. The density of $-\mathrm{SO}_{3} \mathrm{H}$ sites in the catalyst was calculated to be $0.70 \mathrm{mmol} / \mathrm{g}$ from the $\mathrm{S}$ content (Table 1). The value determined by titration was 0.62 $\mathrm{mmol} / \mathrm{g}$, which matched the value obtained using the XPS, and was comparable to those of catalysts from wood chips $[3,21]$. As the data in Table 1 show, the specific surface area of the catalyst was low. Assuming that all the $-\mathrm{SO}_{3} \mathrm{H}$ groups were located on the surface of the catalyst, $1 \mathrm{~nm}^{2}$ would accommodate one $\mathrm{S}$ atom. This is impossible because the radius of the $\mathrm{S}$ atom is $0.1 \mathrm{~nm}$, so there must be some $-\mathrm{SO}_{3} \mathrm{H}$ groups present in the bulk of the unexpanded catalyst. The average pore size of the catalyst was greater than $2 \mathrm{~nm}$, indicating that there was a

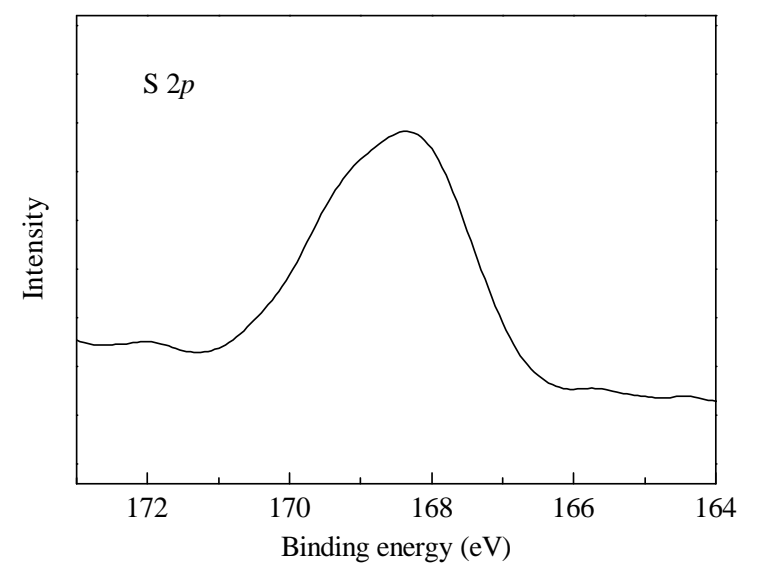

Fig. 2. XPS spectrum of solid acid catalyst obtained from rice husk char.
Table 1

Ultimate analysis and textural property of solid acid catalyst obtained from rice husk char.

\begin{tabular}{|c|c|c|c|c|c|c|c|}
\hline \multicolumn{5}{|c|}{ Ultimate analysis (\%) } & \multicolumn{3}{|c|}{ Textural property } \\
\hline C & $\mathrm{H}$ & 0 & $\mathrm{~N}$ & $S$ & $\begin{array}{c}\text { Surface } \\
\text { area }\left(m^{2} \cdot g^{-1}\right)\end{array}$ & $\begin{array}{l}\text { Pore volume } \\
\left(\mathrm{ml} \cdot \mathrm{g}^{-1}\right)\end{array}$ & $\begin{array}{l}\text { Pore diam- } \\
\text { eter }(\mathrm{nm})\end{array}$ \\
\hline 40.96 & 2.33 & 18.91 & 0.69 & 2.25 & 4 & 0.02 & 7.71 \\
\hline
\end{tabular}

certain amount of mesopores, which was conducive to larger reactant and resultant coming in and out of the pore structure of the catalyst [1], thus improving the catalytic efficiency.

The evolution of $\mathrm{SO}_{2}(\mathrm{~m} / z=64)$ and $\mathrm{SO}_{3}(\mathrm{~m} / z=80)$ with changing temperature was determined by TG-MS, as illustrated in Fig. 3. Evolution of $\mathrm{SO}_{2}$ was observed in the high temperature region from $180{ }^{\circ} \mathrm{C}$ to $680^{\circ} \mathrm{C}$, in which there were three evolution peaks with different intensity. The largest one appeared at around $300{ }^{\circ} \mathrm{C}$, and the other two emerged at about $500{ }^{\circ} \mathrm{C}$ and $640{ }^{\circ} \mathrm{C}$. In the pyrolysis process, however, no peak for the evolution of $\mathrm{SO}_{3}$ was detected. This showed that the $-\mathrm{SO}_{3} \mathrm{H}$ groups in the catalyst had excellent heat stability, and they only decomposed slowly to $\mathrm{SO}_{2}$ in the temperature range $180-680{ }^{\circ} \mathrm{C}$ $[13,24]$.

\subsection{Performance of solid acid catalyst}

\subsubsection{Influence of preparation conditions on catalyst activity}

The sulfonation temperature and time are important factors affecting the structure and activity of the carbon-derived catalyst $[16,20]$. For different materials, suitable sulfonation conditions are varied. In this work, the effects of the sulfonation conditions on the catalyst activity were investigated, as shown in Fig. 4. As can be seen in Fig. 4(a), the conversion of oleic acid initially increased with increasing sulfonation temperature and then decreased. The best sulfonation temperature was $90{ }^{\circ} \mathrm{C}$; the catalyst showed the highest activity at this temperature, and the oleic acid conversion was 98.7\%. As shown in Fig. 4(b), the oleic acid conversion remained nearly stable at about $98.0 \%$ over the time from $0.25 \mathrm{~h}$ to $4 \mathrm{~h}$, indicating that the catalyst activity did not change significantly with increasing sulfonation time. This was identical to the effect of the sulfonation time on charcoal powder [16], showing that the sulfonation of



Fig. 3. Evolution of $\mathrm{SO}_{2}$ and $\mathrm{SO}_{3}$ from solid acid catalyst obtained from rice husk char under helium detected using TG-MS. 

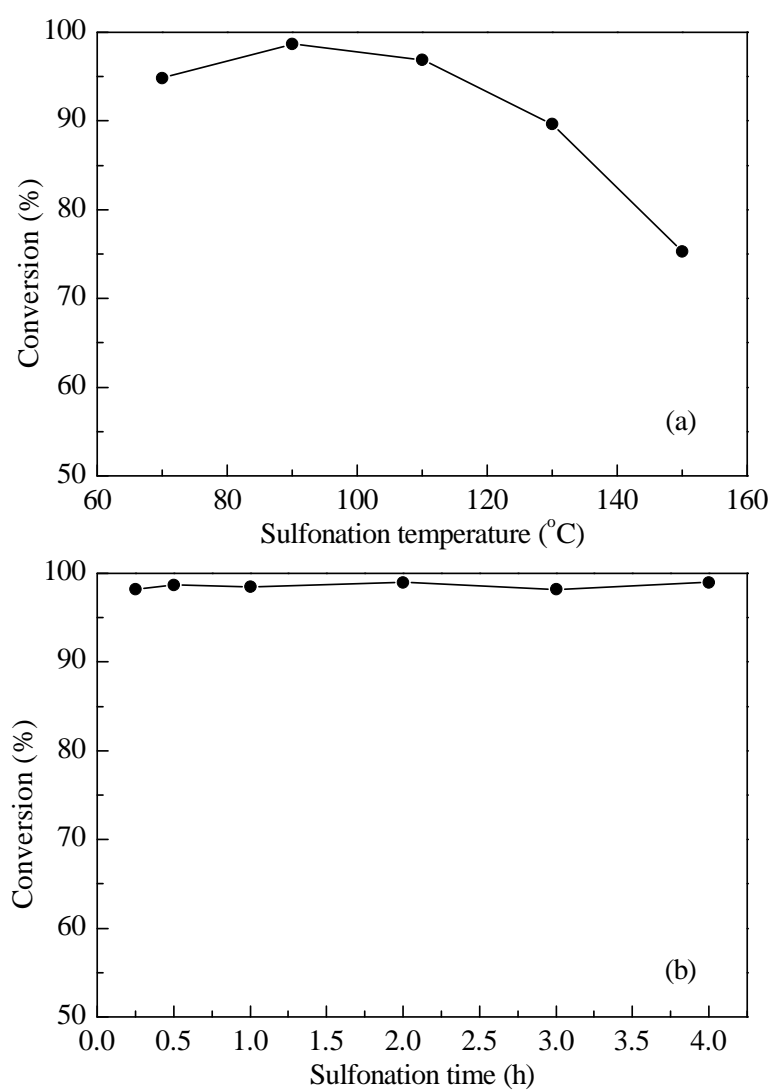

Fig. 4. Effects of sulfonation conditions on esterification of oleic acid with methanol catalyzed by catalyst obtained from rice husk char. (a) sulfonation temperature (sulfonation time $2 \mathrm{~h}$ ); (b) Sulfonation time (sulfonation temperature $90^{\circ} \mathrm{C}$ ). Reaction conditions: catalyst amount $5 \%$, methanol to oleic acid molar ratio $6: 1,120^{\circ} \mathrm{C}, 2 \mathrm{~h}$.

rice husk char with concentrated sulfuric acid was relatively fast, and a sulfonated product with excellent stability was formed in a short time.

Taken together, appropriate conditions for preparation of solid acid catalyst from rice husk char were found to be a sulfonation temperature of $90^{\circ} \mathrm{C}$ and a reaction time of $0.25 \mathrm{~h}$. The preparation was therefore not only simple but was also rapid and energy efficient.

\subsubsection{Influence of reaction conditions on catalyst activity}

The effects of catalyst amount, methanol to oleic acid molar ratio, reaction temperature, and reaction time on the conversion of oleic acid are shown in Fig. 5. Figure 5(a) shows that when the catalyst amount was below 5\%, the conversion of oleic acid increased significantly with increasing catalyst amount, from $6.0 \%$ with no catalyst to $98.7 \%$ with $5 \%$ catalyst. However, further increases in the catalyst amount had little effect on the conversion of oleic acid. As can be seen from Fig. 5(b), the trend in the effect on oleic acid conversion of the methanol to oleic acid molar ratio was the same as that of the catalyst amount. As shown in Fig. 5(c), with increasing esterification temperature, the conversion of oleic acid increased quickly below the inflection temperature of $100{ }^{\circ} \mathrm{C}$, but then increased slowly. Raising the temperature drives the equilibrium toward the products because the esterification reaction of oleic acid with methanol is reversible and endothermic. When the temperature was increased from 65 to $100{ }^{\circ} \mathrm{C}$, water formed in the reactor was efficiently removed using the continuous esterification apparatus, resulting in increased oleic acid conversion. However, the water-removing capacity of the equipment reached its limit when the temperature was about $100{ }^{\circ} \mathrm{C}$, so the oleic acid conversion rate became slower. The conversion of oleic acid was $98.5 \%$ when the esterification temperature was set at $110^{\circ} \mathrm{C}$. As shown in Fig. 5(d), the esterification reaction basically approached equilibrium after $2 \mathrm{~h}$ in the presence of the catalyst.

In summary, the conversion of oleic acid was more than $98.0 \%$ under the optimal reaction conditions (catalyst amount $5 \%$, methanol to oleic acid molar ratio $4: 1$, reaction temperature $110{ }^{\circ} \mathrm{C}$ and time $2 \mathrm{~h}$ ), and the catalyst showed good catalyst activity in the esterification reaction. In order to further investigate the catalyst activity, its performance in the esterification reaction was compared with that of concentrated sulfuric acid and Amberlyst-15, a commonly used solid acid catalyst. Under the optimal conditions described above, the conversion of oleic acid with concentrated sulfuric acid and Amberlyst-15 as catalysts was $97.2 \%$ and $88.6 \%$, respectively; the corresponding conversion was $96.2 \%$ and $27.9 \%$ when the reaction time was reduced to $0.5 \mathrm{~h}$. These results showed that the cata-

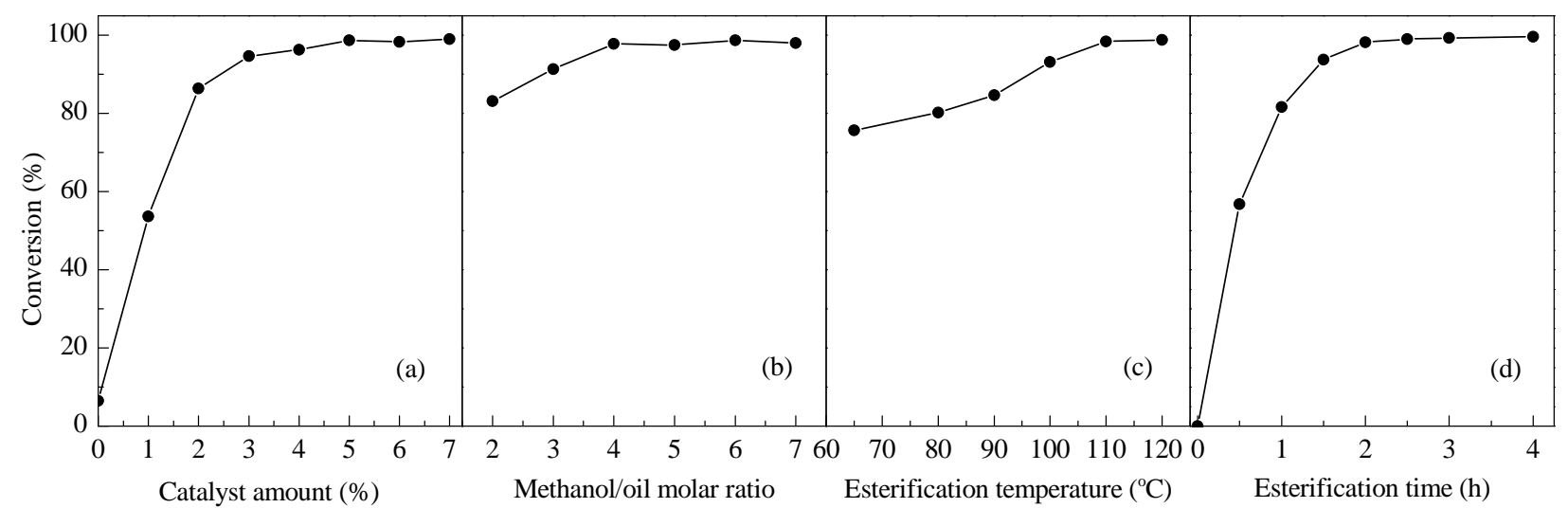

Fig. 5. Effects of reaction conditions on conversion of oleic acid. (a) Catalyst amount (methanol to oleic acid molar ratio 6:1, $120^{\circ} \mathrm{C}, 2 \mathrm{~h}$ ); (b) Methanol to oleic acid molar ratio (catalyst amount $5 \%, 120^{\circ} \mathrm{C}, 2 \mathrm{~h}$ ); (c) Esterification temperature (catalyst amount $5 \%$, methanol to oleic acid molar ratio $4: 1$, $2 \mathrm{~h}$ ); (d) Esterification time (catalyst amount 5\%, methanol to oleic acid molar ratio 4:1,110 ${ }^{\circ} \mathrm{C}$ ). 
lytic activity of the solid acid catalyst was worse than that of concentrated sulfuric acid, but significantly better than that of Amberlyst-15. However, using concentrated sulfuric acid as a catalyst in the esterification process increases the cost of equipment manufacture and product separation, and also decreases the glycerol purity, making the biodiesel production less profitable. Marchetti et al. [27] studied the economy of biodiesel and the results showed that the use of heterogeneous catalysts gave the best economic competitiveness, the use of concentrated sulfuric acid for pre-esterification and then a heterogeneous catalyst for transesterification came second, and the use of a liquid acid was worst. It can be inferred that the as-prepared catalyst has good potential for application in the preparation of biodiesel.

\subsubsection{Catalyst stability}

The stability of a catalyst is an important factor in measuring its performance. In the pre-esterification of waste oils, using a catalyst of good stability will reduce the pretreatment cost, thus lowering the cost of the material for biodiesel production.

In order to investigate the stability of the catalyst prepared from rice husk char, two experiments with esterification time of $2 \mathrm{~h}$ and $3 \mathrm{~h}$, respectively were carried out. In each case, the catalyst was repeatedly used for seven cycles (Fig. 6). The results showed that the oleic acid conversion decreased over seven cycles, no matter how long the reaction time was, but the conversion decreased more significantly for the shorter reaction time. For example, the oleic acid conversion was $87.9 \%$ and $96.0 \%$ in the sixth cycle when the corresponding reaction time was $2 \mathrm{~h}$ and $3 \mathrm{~h}$, respectively; the corresponding conversion was $84.3 \%$ and $95.2 \%$ in the seventh cycle. This proved that the catalyst had excellent stability. Although the catalyst unfolded and the $-\mathrm{SO}_{3} \mathrm{H}$ groups in the bulk could also participate in the esterification when the catalyst was mixed with the reactants, thus enhancing its catalytic activity $[4,14]$, leaching of $-\mathrm{SO}_{3} \mathrm{H}$ groups from the reaction system might occur. The catalyst recovered after seven runs (the reaction time was $2 \mathrm{~h}$ ) was characterized by ultimate analysis. The results showed that the $S$ content of the recovered catalyst was $1.74 \%$, a decrease of $22.67 \%$ relative to the fresh catalyst. Accordingly, it can be

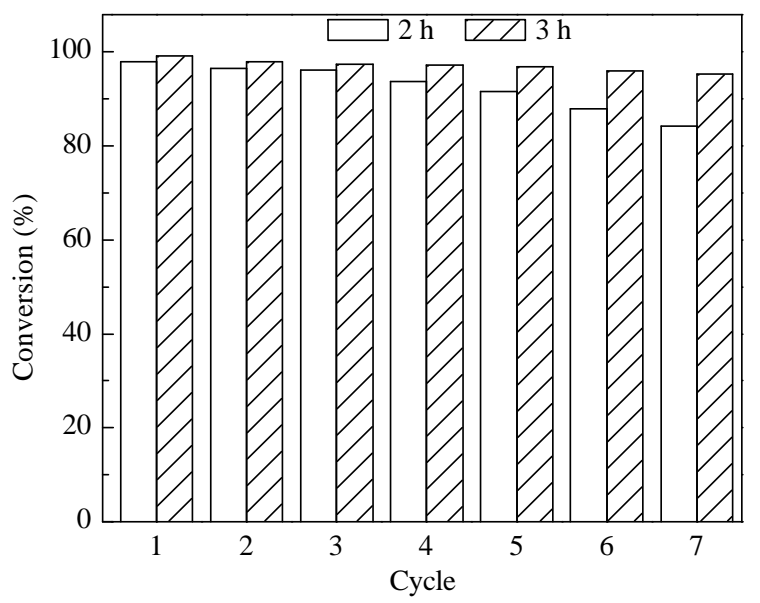

Fig. 6. Stability of solid acid catalyst obtained from rice husk char. inferred that the slight decline in the esterification activity of the catalyst was caused by leaching of some $-\mathrm{SO}_{3} \mathrm{H}$ groups; this is in agreement with the results of Mo et al. $[14,15]$.

\section{Conclusions}

The preparation of the solid acid catalyst from rice husk char was simple, rapid, and energy efficient. Suitable sulfonation temperature and time were $90{ }^{\circ} \mathrm{C}$ and $0.25 \mathrm{~h}$, respectively. The catalyst prepared under the optimal conditions had amorphous carbon structure with a large number of sulfonic groups. It exhibited good catalytic activity in the esterification of oleic acid with methanol, and the oleic acid conversion was more than $98.0 \%$ under the best reaction conditions. The catalyst had excellent stability, but in practice, because of a slight decrease in the catalytic activity, it was necessary to extend the reaction time appropriately to achieve the required acid value for feedstocks for biodiesel production.

\section{References}

[1] Peng B X, Shu Q, Wang J F, Wang G R, Wang D Z, Han M H. Process Saf Environ Prot, 2008, 86: 441

[2] Semwal S, Arora A K, Badoni R P, Tuli D K. Bioresour Technol, 2011, 102: 2151

[3] Dehkhoda A M, West A H, Ellis N. Appl Catal A, 2010, 382: 197

[4] Lou W Y, Zong M H, Duan Z Q. Bioresour Technol, 2008, 99: 8752

[5] Zong M H, Duan Z Q, Lou W Y, Smith T J, Wu H. Green Chem, 2007, 9: 434

[6] Shu Q, Nawaz Z, Gao J X, Liao Y H, Zhang Q, Wang D Z, Wang J F. Bioresour Technol, 2010, 101: 5374

[7] Math M C, Kumar S P, Chetty S V. Energy Sustainable Dev, 2010, 14: 339

[8] Ren L G, Yu J W, Zhang X L, Gao W Y. Petroleum Process Petroleum (任立国, 余济伟, 张晓丽, 高文艺. 石油炼制与化工), 2009, 40(5): 38

[9] Zhang Y, Dube M A, McLean D D, Kates M. Bioresour Technol, 2003, 90: 229

[10] Jacobson K, Gopinath R, Meher L C, Dalai A K. Appl Catal B, 2008, 85: 86

[11] Geng L, Wang Y, Yu G, Zhu Y X. Catal Commun, 2011, 13: 26

[12] Toda M, Takagaki A, Okamura M, Kondo J N, Hayashi S, Domen K, Hara M. Nature, 2005, 438: 178

[13] Hara M, Yoshida T, Takagaki A, Takata T, Kondo J N, Hayashi S, Domen K. Angew Chem Int Ed, 2004, 43: 2955

[14] Mo X H, López D E, Suwannakarn K, Liu Y J, Lotero E, Goodwin J G Jr, Lu C Q.J Catal, 2008, 254: 332

[15] Mo X H, Lotero E, Lu C Q, Liu Y J, Goodwin J G Jr. Catal Lett, 2008, 123: 1

[16] Wu R N, Wang T H, Xiu Z L, Guo F, Pan Y Q Yin J Z. Chin J Catal (乌 日娜，王同华，修志龙，郭峰，潘艳秋，银建中. 催化学报)，2009， 30: 1203

[17] Okamura M, Takagaki A, Toda M, Kondo J N, Domen K, Tatsumi T, Hara M, Hayashi S. Chem Mater, 2006, 18: 3039

[18] Takagaki A, Toda M, Okamura M, Kondo J N, Hayashi S, Domen K, Hara M. Catal Today, 2006, 116: 157

[19] Chen G, Fang B S. Bioresour Technol, 2011, 102: 2635

[20] Lou W Y, Cai J, Duan Z Q, Zong M H. Chin J Catal (娄文勇, 蔡俊, 段 章群, 宗敏华. 催化学报), 2011, 32: 1755 


\title{
Graphical Abstract
}

Chin. J. Catal., 2013, 34: 1674-1682 doi: 10.1016/S1872-2067(12)60634-2

\section{Preparation of solid acid catalyst from rice husk char and its catalytic performance in esterification}

Ming Li, Dengyu Chen, Xifeng Zhu*

University of Science and Technology of China

A solid acid catalyst with high $-\mathrm{SO}_{3} \mathrm{H}$ density and excellent stability was prepared from rice husk char and was used to pre-esterify materials with high fatty acid contents for biodiesel production.

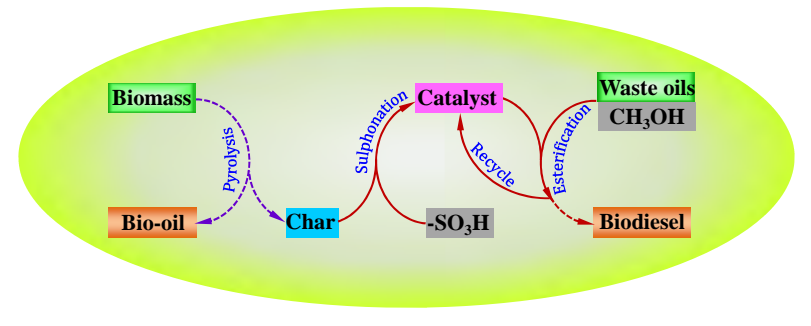

[21] Kastner J R, Miller J, Geller D P, Locklin J, Keith L H, Johnson T. Catal Today, 2012, 190: 122

[22] Mohan D, Pittman C U Jr, Steele P H. Energy Fuels, 2006, 20: 848

[23] Benak K R, Dominguez L, Economy J, Mangun C L. Carbon, 2002, 40: 2323

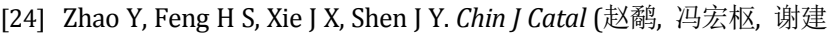

新, 沈俭一. 催化学报), 2011, 32: 688

[25] Wang Y, Ou S Y, Liu P Z, Zhang Z S. Energy Convers Manage, 2007, 48: 184

[26] Wang S J. Carbon Tech (汪树军. 炭素技术), 2000, (6): 8

[27] Marchetti J M, Miguel V U, Errazu A F. Fuel Process Technol, 2008, 89: 740

\section{稻壳炭基固体酸催化剂的制备及其催化酯化反应性能}

\author{
李明, 陈登宇, 朱锡锋* \\ 中国科学技术大学安徽省生物质洁净能源重点实验室, 安徽合肥230026
}

摘要: 以热解稻壳炭为原料, 浓硫酸为磺化剂制备了固体酸催化剂. 采用X射线衍射、X射线光电子能谱、元素分析、孔结构分 析和热重-质谱联用等手段对其进行了表征. 以油酸和甲醇的酯化为探针反应, 考察了磺化温度和时间对催化剂活性的影响, 探讨 了反应条件对油酸转化率的影响, 并对所制催化剂的稳定性进行了研究. 结果表明, 制备该催化剂的适宜磺化温度和时间分别为 $90{ }^{\circ} \mathrm{C}$ 和 $0.25 \mathrm{~h}$, 在该条件下制得的催化剂为无定形碳结构, 磺酸基密度为 $0.7 \mathrm{mmol} / \mathrm{g}$. 该催化剂表现出较高的催化酯化反应活性, 在催化剂用量为 $5 \%$ 、甲醇/油酸摩尔比为 4 、醌化温度和时间分别为 $110{ }^{\circ} \mathrm{C}$ 和 $2 \mathrm{~h}$ 的条件下, 油酸的酯化率可达 $98.7 \%$. 该催化剂具 有较好的稳定性, 经7次连续反应后, 油酸的酯化率仍可达 $96.0 \%$.

关键词: 稻壳炭; 固体酸催化剂; 生物柴油; 酯化

收稿日期: 2013-04-02. 接受日期: 2013-05-31. 出版日期: 2013-09-20.

*通讯联系人. 电话: (0551)63600040; 传真: (0551)63606689; 电子信箱: xfzhu@ustc.edu.cn 基金来源：国家高技术研究发展计划(863计划, 2012AA051803); 国家自然科学基金(50930006); 中国科学院重点部署项目 (KGZD-EW-304-3).

本文的英文电子版由Elsevier出版社在ScienceDirect上出版(http://www.sciencedirect.com/science/journal/18722067).

\section{1. 前言}

作为一种绿色能源, 生物柴油具有含硫量低、不含 芳香族烷烃、无毒、易被微生物降解、闪点高、十六烷 值高和润滑性好等优点 ${ }^{[1,2]}$. 目前, 国内外生产生物柴油 的主要方法为酯交换法 ${ }^{[2]}$. 它是指在催化剂作用下或在 超临界条件下, 油料主要成分甘油三酯与低碳醇发生醇 解反应, 生成相应的脂肪酸酯即生物柴油. 现阶段, 制约 生物柴油产业发展的主要因素是过高的原料成本 ${ }^{[3-6]}$; 据统计，原料成本占生物柴油制备成本的 $70 \%-95 \%{ }^{[7-9]}$. 采用廉价原料(如餐饮废油、非食用油、动物油脂和皇 脚)降低成本是实现生物柴油产业化、市场化的关键 ${ }^{[10]}$.
但餐饮废油和非食用油等脂肪酸含量过高, 对酯交换法 制备生物柴油十分不利(酯交换法要求原料酸值最好小 于 $1.5 \mathrm{mg} \mathrm{KOH} / \mathrm{g})^{[6,8]}$. 因此, 以餐饮废油等为原料生产生 物柴油时必须进行预酯化降酸处理 ${ }^{[1,5]}$. 这一过程通常 以浓硫酸为催化剂 ${ }^{[11,12]}$, 但存在设备腐蚀严重、催化剂 难以回收和废水产生量大等缺点.

近年来, 以糖类化合物或木质纤维素类生物质为原 料, 经不完全炭化和磺化制备的炭基固体酸催化剂, 由 于其低廉的制备成本和较高的催化活性, 引起了国内外 学者的广泛关注 ${ }^{[5,13-21]}$. 不同研究者对由不同原料制备 的炭基固体酸催化剂进行了研究. Toda课题组 ${ }^{[17,18]}$ 以葡 萄糖和蔗糖为原料, 经不完全炭化后通过浓硫酸和发烟 
硫酸制得固体酸催化剂, 并用于乙酸和油酸的酯化反应. 结果表明, 在乙酸乙酯的合成中, 炭基固体酸的催化效 果为浓硫酸的 $1 / 7$; 而在油酸乙酯的合成中, 其催化效果 为浓硫酸的 $1 / 2$, 但都明显优于传统的固体酸铌酸. Chen 等 ${ }^{[19]}$ 以葡萄糖和淀粉的混合物制得固体酸催化剂, 并将 它用于油酸和甲醇的酯化反应. 结果表明, 该催化剂表 现出较高的催化酯化反应活性, 在甲醇和油酸的摩尔比 为 10 , 反应温度为 $80^{\circ} \mathrm{C}$ 时, 经 $6 \mathrm{~h}$ 后油酸的转化率可达 $96 \%$. 娄文勇等 ${ }^{[20]}$ 研究了由葡萄糖、蔗糖、淀粉和纤维 素四种原料制备的固体酸催化剂的酯化活性和转酯化 活性. 结果表明, 由淀粉制得的固体酸催化剂活性最高, 其活性几乎与浓硫酸相当. Kastner等 ${ }^{[21]}$ 通过热解花生 壳和木屑得到生物质炭, 然后用浓硫酸磺化制得固体酸 催化剂, 它们对催化棕榈酸和硬脂酸的酯化反应均表现 出较高的活性, 棕榈酸转化率可接近 $100 \%$. 另一方面, 在生物质快速热解制备生物油的过程中产生约 15\%-25\%的热解焦炭 ${ }^{[22]}$, 它们能否被充分有效利用将直 接影响到生物质热解液化技术的经济效益.

本文以稻壳热解制备生物油的副产物热解稻壳炭 为原料, 以油酸和甲醇的酯化为探针反应, 考察制备条 件对固体酸催化剂催化活性的影响, 并探讨催化剂用量 (基于油酸质量)、甲醇/油酸摩尔比、酯化温度和酯化时 间对油酸转化率的影响. 此外, 对所制催化剂的稳定性 也进行了考察.

\section{2. 实验部分}

\section{1. 催化剂的制备}

将热解稻壳炭研成粉末 (粒径 $\leqslant 0.28 \mathrm{~mm}$ ), 在一定 温度下用浓硫酸(95\%-98\%)磺化一定时间(炭粉质量与 浓硫酸体积比为 $1 \mathrm{~g}: 10 \mathrm{ml}$ ) 后冷却至室温. 将冷却的固 液混合物加入到一定量的蒸馏水中, 搅拌, 过滤, 之后对 固体沉淀物用热蒸馏水反复洗涤直至洗液中检测不到 硫酸根离子为止. 在 $80^{\circ} \mathrm{C}$ 下干燥 $24 \mathrm{~h}$ 后将其装入密封 袋, 置于干燥血中备用.

\section{2. 催化剂的表征}

采用德国Elementar公司Vario MICRO型元素分析 仪分析催化剂中 $\mathrm{C}, \mathrm{H}, \mathrm{N}$ 和 S 元素的含量. 采用德国 Elementar公司Vario EL cube型元素分析仪分析催化剂 中O元素的含量. 采用日本MacScience公司MXPAHF型 $\mathrm{X}$ 射线衍射仪对催化剂微结构进行表征, $\mathrm{Cu} K_{\alpha}$ 辐射源, 波长为 $15.4056 \mathrm{~nm}$, 加速电压为 $30.0 \mathrm{kV}$, 管电流为 150.0 $\mathrm{mA}$, 扫描角 $2 \theta$ 的范围为 $10^{\circ}-70^{\circ}$, 扫描速率为 $8^{\circ} / \mathrm{min}$. 采
用美国Thermo-VG Scientific公司ESCALAB 250型X射 线光电子能谱仪分析催化剂表面 $\mathrm{S}$ 的存在形式, $\mathrm{Al} K_{\alpha} \mathrm{X}$ 射线源, $\mathrm{CAE}$ 模式, 能量步长为 $1.00 \mathrm{eV}$. 采用美国 Quantachrome公司Quandasorb SI型孔径分析仪测定催 化剂的比表面积和孔容, 比表面积选 $p / p_{0}=0.05-0.2$ 的吸 附段数据采用BET公式计算, 总孔容根据比压为 $p / p_{0}=$ 0.99 时吸附的液氮体积计算, 平均孔径根据脱附数据采 用BJH方法计算, 所采用的脱气条件为 $100{ }^{\circ} \mathrm{C}$ 氮气氛围 下脱气3 h. 热重-质谱联用(TG-MS)在美国Perkin-Elmer 公司Pyris 1 TGA型热重分析仪和Clarus SQ 8型质谱仪 上进行, 质荷比采用多通道离子检测系统(MID)检测, $\mathrm{He}$ 氛围, 流量为 $50 \mathrm{ml} / \mathrm{min}$, 热重以 $10^{\circ} \mathrm{C} / \mathrm{min}$ 从室温升温到 $800{ }^{\circ} \mathrm{C}$. 催化剂的强酸量由酸碱滴定法测定 ${ }^{[23,24]}$. 步骤 如下: 取所制催化剂 $0.5 \mathrm{~g}$, 加入到 $100 \mathrm{ml}$ 锥形瓶中, 再加 入 $50 \mathrm{ml} \mathrm{NaCl}$ 溶液 $(1 \mathrm{~mol} / \mathrm{L})$, 在超声振荡仪中振荡 30 min, 使催化剂上的 $\mathrm{H}^{+}$和 $\mathrm{Na}^{+}$充分交换, 过滤后的滤液用 $\mathrm{NaOH}$ 溶液 $(0.1 \mathrm{~mol} / \mathrm{L})$ 滴定.

\section{3. 催化剂的评价}

油酸和甲醇的酯化反应在精馏分水连续酯化装 置 ${ }^{[16]}$ 中进行. 该装置由酯化反应器和再沸器两部分组 成, 它的主要优点是在较高的反应温度下可以将在酯化 反应过程中产生的水及时地分离出去, 同时不会造成反 应体系中甲醇的减少.

首先预热反应装置, 当酯化反应器和再沸器温度分 别达到设定温度时 (再沸器温度为 $70^{\circ} \mathrm{C}$ ) 将固体酸催化 剂加入到酯化反应器中, 然后加入油酸和甲醇. 反应时 进行磁力搅拌, 转速为 $800 \mathrm{r} / \mathrm{min}$, 反应一定时间后进行 取样分析.

通过测油相的酸值, 以油酸转化率 $X$ 表示催化剂的 活性 ${ }^{[6,25]}: X=\left(1-\mathrm{AV}_{t} / \mathrm{AV}_{0}\right) \times 100 \%$. 式中, $\mathrm{AV}_{t}$ 为反应 $t$ 时间后油相的酸值, $A V_{0}$ 为油酸的酸值, 酸值按 《GB/T 5530-2005植物油脂酸值测定法》测定.

催化剂的稳定性试验中, 催化剂用量为5\%, 甲醇/油 酸摩尔比为 4 , 酯化反应器和再沸器温度分别为 $110{ }^{\circ} \mathrm{C}$ 和 $70{ }^{\circ} \mathrm{C}$, 反应时进行磁力搅拌, 转速为 $800 \mathrm{r} / \mathrm{min}$, 反应一 定时间后将催化剂从反应体系中滤出 ${ }^{[4]}$, 再在相同的反 应条件下进行下一轮反应.

\section{3. 结果与讨论}

\section{1. 催化剂的结构}

稻壳炭基固体酸催化剂的XRD谱示于图1. 可以看 出, 稻壳炭基固体酸催化剂只在 $2 \theta=22.3^{\circ}$ 处出现一个宽 
阔的馒头峰, 它属于(002)晶面的特征衍射峰, 而(100)和 (004)等晶面的特征峰并没有出现. 这说明该催化剂石 墨化程度较低, 为无定形碳结构 ${ }^{[26]}$. 由于以石墨、炭黑 和玻璃碳等为原料制备的固体酸催化剂在催化酯化反 应时没有活性 ${ }^{[13]}$, 因此可以推测, 无定形碳结构可能在 固体酸催化剂催化酯化反应的过程中起到重要的作 用 ${ }^{[5,8]}$.

图2为稻壳炭基固体酸催化剂表面 $S 2 p$ 的XPS谱. 可以看出, 样品在 $168.4 \mathrm{eV}$ 处出现了一个较强的峰, 表明 该催化剂中 $S$ 均存在于磺酸基 $\left(-\mathrm{SO}_{3} \mathrm{H}\right)$ 中 $^{[17-19]}$, 从而可以 由 $\mathrm{S}$ 含量(见表1)计算出 $-\mathrm{SO}_{3} \mathrm{H}$ 含量, 其值为 $0.70 \mathrm{mmol} / \mathrm{g}$. 另外, 通过酸碱滴定法测得的 $-\mathrm{SO}_{3} \mathrm{H}$ 量为 $0.62 \mathrm{mmol} / \mathrm{g}$. 可见, 由两种方法得到的 $-\mathrm{SO}_{3} \mathrm{H}$ 含量基本一致, 其与以 木屑为原料制备的固体酸催化剂的 $-\mathrm{SO}_{3} \mathrm{H}$ 含量相当 ${ }^{[3,21]}$. 此外, 由表1中孔结构参数可知, 该催化剂比表面积较低. 假设 $-\mathrm{SO}_{3} \mathrm{H}$ 只存在于催化剂的表面, 则 $1 \mathrm{~nm}^{2}$ 的表面平均 须容纳约 1 个 $\mathrm{S}$ 原子, 由 $\mathrm{S}$ 原子的半径为 $0.1 \mathrm{~nm}$ 可知, 这是 不可能的, 因此必然有一部分- $\mathrm{SO}_{3} \mathrm{H}$ 分布在催化剂的内 部. 另一方面, 该催化剂平均孔径大于 $2 \mathrm{~nm}$, 表明它含有 一定量的介孔, 这有利于大分子的反应物和生成物通过 催化剂孔道 ${ }^{[1]}$, 确保催化剂内部活性位和反应物的接触, 从而提高催化效率.

采用TG-MS检测得到所制催化剂在 He氛围下分解 时生成的 $\mathrm{SO}_{2}(\mathrm{~m} / \mathrm{z}=64)$ 和 $\mathrm{SO}_{3}(\mathrm{~m} / \mathrm{z}=80)$ 随温度的变化 情况如图3. 可以看出, $\mathrm{SO}_{2}$ 在 $180-680^{\circ} \mathrm{C}$ 的较大温度范 围内均有产生, 主要形成三个大小各异的峰, 最大的峰 值出现在 $300^{\circ} \mathrm{C}$ 左右, 其余两个较小的峰值分别出现在 $500{ }^{\circ} \mathrm{C}$ 和 $640^{\circ} \mathrm{C}$ 附近, 而在整个热解温度段没有检测到 明显的 $\mathrm{SO}_{3}$ 信号. 这说明稻壳炭基固体酸催化剂中的 $-\mathrm{SO}_{3} \mathrm{H}$ 具有较高的热稳定性, 在 $180^{\circ} \mathrm{C}$ 以下基本不会发 生分解, 只有当温度进一步升高, 它才逐渐以 $\mathrm{SO}_{2}$ 的方式 分解 ${ }^{[13,24]}$, 直到温度升至 $680{ }^{\circ} \mathrm{C}$, 所有的 $-\mathrm{SO}_{3} \mathrm{H}$ 才全部分 解.

\section{2. 催化剂的性能}

\subsection{1. 制备条件对催化剂活性的影响}

磺化温度和磺化时间是影响催化剂结构和活性的 两个重要参数 ${ }^{[16,20]}$; 对于不同的原料, 最佳磺化温度和 时间有所不同. 为了得到稻壳炭基固体酸催化剂的最佳 磺化条件, 本文进行了磺化温度和磺化时间对催化剂活 性影响的实验, 结果如图4所示. 由图4(a)可见, 随着磺 化温度的升高, 油酸转化率先升高后降低, 当磺化温度 为 $90{ }^{\circ} \mathrm{C}$ 时, 催化剂活性最高, 油酸转化率达 $98.7 \%$; 而由 图4(b)可以看出, 随着磺化时间从 $0.25 \mathrm{~h}$ 延长到 $4 \mathrm{~h}$, 油酸 转化率基本保持在 $98.0 \%$ 左右. 这说明催化剂的活性并 没有随磺化时间延长而发生明显变化, 这与磺化时间对 木质炭粉的影响规律相同 ${ }^{[16]}$, 表明浓硫酸与稻壳炭的磺 化反应比较剧烈, 在较短的时间内就形成了比较稳定的 磺化产物。

综上所述, 以热解稻壳炭为原料制备固体酸催化剂 的适宜磺化温度和时间分别为 $90{ }^{\circ} \mathrm{C}$ 和 $0.25 \mathrm{~h}$. 可见, 制 备该催化剂不仅工艺过程简单, 而且具有需时短、能耗 低的优点.

\subsection{2. 反应条件对催化剂活性的影响}

催化剂用量(基于油酸质量)、甲醇/油酸摩尔比、酯 化温度和酯化时间对稻壳炭基固体酸催化剂催化油酸 和甲醇酯化反应活性的影响示于图5. 由图5(a)可以看 出, 当催化剂用量不高于 $5 \%$ 时, 随着催化剂用量的增加, 油酸酯化率显著提高, 从不加催化剂时的 $6.0 \%$ 提高到催 化剂用量为 $5 \%$ 时的 $98.7 \%$, 而当继续加大催化剂用量时, 油酸酯化率并没有明显升高. 因此, 最佳的催化剂用量 为5\%. 由图5(b)可以看出, 油酸酯化率随甲醇/油酸摩尔 比的增加也是先快速升高后基本保持不变. 可见, 最合 适的醇油摩尔比为4. 由图5(c)可见, 随着酯化温度的升 高, 油酸酯化率增速由快变缓, 在 $100{ }^{\circ} \mathrm{C}$ 时出现拐点. 由 油酸和甲醇的酯化反应为可逆吸热反应知, 一方面, 温 度升高有利于反应向正方向进行, 提高油酸酯化率; 另 一方面, 当温度从 $65^{\circ} \mathrm{C}$ 升高到 $100{ }^{\circ} \mathrm{C}$ 时, 精馏分水连续 酯化反应装置的 “分水” 效果越来越好, 从而及时将生 成的水从反应体系中分离出去, 进一步提高了油酸的酯 化率, 但随着温度的继续升高, 由于精馏分水连续酯化 反应装置的 “分水” 能力在 $100{ }^{\circ} \mathrm{C}$ 时已达极限, 从而导 致油酸酯化率增速变缓, 当温度为 $110^{\circ} \mathrm{C}$ 时, 油酸的酯 化率达到 $98.5 \%$. 因此, 选择酯化温度为 $110^{\circ} \mathrm{C}$. 图5(d) 表明, 在稻壳炭基固体酸催化剂的作用下, 油酸和甲醇 的酯化反应在 $2 \mathrm{~h}$ 后基本达到反应平衡. 所以, 最佳的酯 化时间为 $2 \mathrm{~h}$.

综上所述, 在稻壳炭基固体酸催化剂用量为 $5 \%$ 、醇 油摩尔比为 4 、酯化温度和酯化时间为分别为 $110{ }^{\circ} \mathrm{C}$ 和 2 $\mathrm{h}$ 的最优条件下, 油酸的酯化率可达 $98.0 \%$ 以上, 表现出 较高的催化酯化反应活性. 为了进一步考察稻壳炭基固 体酸催化剂的活性, 本文还将其与浓硫酸和另一种常用 于酯化反应的固体酸催化剂Amberlyst-15进行了对比. 在上述优化条件下, 浓硫酸催化油酸的转化率为 $97.2 \%$, Amberlyst-15催化油酸的转化率为 $88.6 \%$; 而在其它条 
件相同, 酯化时间为 $0.5 \mathrm{~h}$ 时, 浓硫酸和Amberlyst-15催化 油酸的酯化率分别为 $96.2 \%$ 和 $27.9 \%$. 可见, 稻壳炭基固 体酸催化剂的催化性能不及浓硫酸, 但明显优于 Amberlyst-15. 在对油脂原料进行降酸预处理时, 以浓硫 酸作催化剂相对固体酸催化剂会增加设备制造和产物 分离成本, 并降低甘油纯度, 进而影响整个过程的经济 效益. Marchetti等 ${ }^{[27]}$ 对生物柴油经济性的研究结果表 明, 用固体酸催化剂催化生产生物柴油时经济性最好, 用均相酸碱两步法催化生产生物柴油时次之, 直接用浓 硫酸催化生产生物柴油时经济性最差. 由此可见, 该催 化剂在生物柴油制备过程中有着较大的应用潜力.

\subsection{3. 催化剂的稳定性}

催化剂的稳定性是衡量催化剂性能的一个重要指 标, 在高酸值油脂的降酸预处理过程中, 使用稳定性优 良的催化剂有助于降低预处理成本, 从而进一步保证生 物柴油生产原料的廉价.

为了考察稻壳炭基固体酸催化剂的稳定性, 本文进 行了单次反应时间分别为 $2 \mathrm{~h}$ 和 $3 \mathrm{~h}$ 的两组实验, 每组催 化剂重复实验7次, 结果如图6所示. 可以看出, 在两种情 况下, 所制催化剂经连续7次使用, 油酸的酯化率均有所 降低, 但单次反应时间为 $2 \mathrm{~h}$ 时油酸酯化率降低幅度更 大. 例如, 在第 6 轮反应中, 反应时间为 $2 \mathrm{~h}$ 的油酸酯化率
为 $87.9 \%$, 反应时间为 $3 \mathrm{~h}$ 的油酸酯化率为 $96.0 \%$; 在第 7 轮反应中, 反应时间为 $2 \mathrm{~h}$ 的油酸酯化率为 $84.3 \%$, 反应 时间为 $3 \mathrm{~h}$ 的油酸酯化率为 $95.2 \%$. 可见, 该催化剂具有 较好的稳定性. 虽然当催化剂和反应物混合时, 催化剂 发生溶胀, 内部的 $-\mathrm{SO}_{3} \mathrm{H}$ 也会参与到催化反应中去, 使 催化剂的活性增强 ${ }^{[4,14]}$, 油酸转化率升高, 但在催化过程 中, 反应物和生成物还有可能使 $-\mathrm{SO}_{3} \mathrm{H}$ 脱落, 从而导致 催化剂活性降低. 对重复使用7次后(每次反应时间为 2 h)的催化剂进行了元素分析. 结果表明, 样品中的S含量 为 $1.74 \%$, 相对于新制备的催化剂减少了 $22.67 \%$. 因此 可以推断, 该催化剂活性的降低是由部分 $-\mathrm{SO}_{3} \mathrm{H}$ 脱落引 起的, 这与 Mo等 ${ }^{[14,15]}$ 的研究结论是一致的.

\section{4. 结论}

以稻壳炭为原料制备固体酸催化剂不仅工艺过程 简单, 而且需时短, 能耗低. 在磺化温度和时间分别为 $90{ }^{\circ} \mathrm{C}$ 和 $0.25 \mathrm{~h}$ 的条件下制备的稻壳炭基固体酸催化剂 具有较高的 $-\mathrm{SO}_{3} \mathrm{H}$ 密度, 为无定形碳结构. 该催化剂可 高效催化油酸和甲醇的酯化反应, 在最佳反应条件下, 油酸的酯化率可达 $98.0 \%$ 以上, 且催化剂具有较好的稳 定性. 而在实际应用过程中, 针对它活性的降低, 可以通 过适当延长反应时间来达到所要求的降酸效果. 